УДК 349.6

DOI https://doi.org/10.32849/2663-5313/2020.1.16

Наталія Махно,

аспірант 4 року навчання

ДВНЗ «Прикарпатський національний університет імені Василя Стефаника»

\title{
ЮРИДИЧНА ВІДПОВІДАЛЬНІСТЬ ЗА ПОРУШЕННЯ ЗАКОНОДАВСТВА ПРО ВОДНІ ОБ'ЄКТИ, ЩО ВІДНЕСЕНІ ДО КАТЕГОРІЇ ЛІКУВАЛЬНИХ
}

На підставі проведеного дослідження у статті вказується, що проблема юридичної відповідальності за порушення законодавства у сфері використання та охорони водних об'єктів, що віднесені до категорії лікувальних, є не вирішеною комплексно в українському законодавстві. I досі точаться наукові дискусії щодо розуміння самої сутності юридичної відповідальності, ї̈ видів тощо.

3 урахуванням сучасних наукових позијій як теоретиків права, так і представників галузевих юридичних наук, зокрема у сфері екологічного права, пропонується розглядати юридичну відповідальність, у тому числі юридичну відповідальність за порушення законодавства у сфері використання та охорони водних об'єктів, що віднесені до категорії лікувальних, як обов'язок правопорушників понести несприятливі наслідки своєї неправомірної поведінки - застосування санкиій кримінально-правового, адміністративного, иивільно-правового, дисииплінарного характеру за вчинення правопорушення, передбаченого нормами природоресурсного та природоохоронного права тощо.

Водні об'єкти, що віднесені до категорії лікувальних, мають істотні особливості, що зумовлює потребу диферениійованого правового регулювання відносин, пов'язаних з юридичною відповідальністю у иій сфері. Отже, ия проблема набула методологічного значення, а в перспективі стане світоглядною, що, своєю чергою, зумовлює новий аспект актуальності юридичної відповідальності за порушення законодавства у иій сфері.

Залежно від спещифіки та видів водних об'єктів, що віднесені до категорії лікувальних, обгрунтовано класифікаиію юридичної відповідальності за порушення законодавства у иій сфері на: 1) юридичну відповідальність за порушення законодавства у сфері використання та охорони підземних водних об'єктів, що віднесені до категорії лікувальних, та 2) юридичну відповідальність за порушення законодавства у сфері використання та охорони поверхневих водних об'єктів, що віднесені до категорії лікувальних

Проте найбільш поширеною в сучасний період є класифікація юридичної відповідальності на види за галузевою ознакою.

Юридичну відповідальність за порушення законодавства у сфері використання та охорони водних об'єктів, що віднесені до категорії лікувальних, обгрунтовано пропонується розглядати як двоаспектне явище, що проявляється у негативній (ретроспективній) та позитивній (перспективній) відповідальності.

Ключові слова: юридична відповідальність, позитивна юридична відповідальність, негативна юридична відповідальність, водні об’єкти, що віднесені до категорії лікувальних.

Постановка проблеми. Формування України як правової держави, неминуче актуалізує проблему юридичної відповідальності за порушення законодавства в екологічній сфері та її пріоритетне місце в системі соціальної відповідальності, зокрема моральної, політичної тощо. Це також визначається істотною екологічною значущістю та великою цінністю для суспільства природних об’єктів, якими є водні об'єкти, що віднесені до категорії лікувальних, та які використовуються для лікування та оздоровлення людей. На жаль, як екологічне законодавство в цілому, так і законодавство, яке встановлюе санкції за порушення вимог щодо використання та охорони водних об'єктів, зокрема і тих, що віднесені до категорії лікувальних, тривалий час в Україні не зазнавало змін, хоча для цього вже склались об'єктивні передумови.

Аналіз останніх досліджень і публікацій. У роботі аналізувались та використовувалися праці як українських, так і іноземних науковців, які тією чи іншою мірою досліджували проблеми юридичної відповідальності за порушення норм при- 
родоресурсного та природоохоронного законодавства, зокрема: В. І. Андрейцева, М. М. Бринчука, Г. І. Балюк, А. П. Гетьмана В. П. Дубовик, Н. I. Єрофєєва, I. I. Каракаша, Н.Р.Кобецької,О.С.Колбасова,Н.І.Краснова, Н. Р. Малишевої, В. Л. Мунтяна, В. В. Носіка, В. В. Петрова, В. К. Попова, Ю. С. Шемшученка, М. В. Шульги та інших.

Мета цього дослідження - проаналізувати сучасну систему (види) юридичної відповідальності за порушення законодавства про водні об'єкти, що віднесені до категорії лікувальних, з урахуванням нових реалій розвитку суспільних відносин у цій сфері та перспектив удосконалення їх правового регулювання.

Виклад основного матеріалу. В умовах розвитку сучасного суспільства однією з найбільш гострих проблем постала проблема збереження водних об’єктів, зокрема тих, що віднесені до категорії лікувальних. На території України зосереджена велика кількість таких водних об'єктів, проте доводиться констатувати, що їхній стан поступово погіршується. Проте заходи юридичної відповідальності не корелюються з тими шкідливими, негативними наслідками, які мають місще у разі негативного антропогенного впливу на водні об'єкти, що віднесені до категорії лікувальних. Судова практика також, на жаль, засвідчує умовну відсутність проблем у сфері використання та охорони водних об'єктів, що віднесені до категорії лікувальних. На жаль, в Сдиному державному реєстрі судових рішень $є$ мало відомостей про притягнення до кримінальної відповідальності за порушення законодавства у цій сфері. Лише кілька вироків судів засвідчують проблему використання артезіанських свердловин без спеціальних дозволів [1]. Аналогічна ситуація - із притягненням винних осіб до адміністративної відповідальності. Тому не виникає сумнівів у необхідності посилення відповідальності за порушення законодавства у сфері використання та охорони водних об'єктів, що віднесені до категорії лікувальних, проте також необхідно докладати і чимало зусиль щодо неможливості уникнення відповідальності за порушення вимог законодавства у сфері використання та охорони водних об'єктів, що віднесені до категорії лікувальних. I в цьому проявляється в тому числі виховний та профілактичний аспекти юридичної відповідальності.

Щодо юридичної відповідальності, зокрема і юридичної відповідальності за порушення екологічного законодавства, у правознавстві існує велике різноманіття поглядів. Насправді, юридична відповідаль- ність є складним і багатоплановим явищем. Вона розглядається в різних значеннях, що зумовило появу різних концепцій юридичної відповідальності.

Наприклад, М. В. Шульга вважає, що суть юридичної відповідальності виражається в негативних наслідках, які зобов'язаний понести порушник екологічних вимог у межах, встановлених екологічним законодавством за правопорушення в галузі екологіï [2, c. 171].

Тим не менше важливою ознакою юридичної відповідальності залишається взаємозв'язок юридичної відповідальності 3 державним примусом, що проявляється у вигляді санкцій за правопорушення. Отже, на наш погляд, юридична відповідальність за правопорушення у сфері використання та охорони водних об'єктів, що віднесені до категорії лікувальних, полягає у застосуванні державними органами примусових заходів майнового, організаційного характеру до осіб, які вчинили відповідні правопорушення. Хоча і не в усіх випадках має місце державний примус, наприклад у випадку дисциплінарної відповідальності, проте сам факт понесення несприятливих для правопорушника негативних наслідків передбачає певний примус, хоч і не з боку державних органів.

Н. Р. Кобецька підкреслює, що юридична відповідальність за екологічні правопорушення $€$ комплексним міжгалузевим інститутом екологічного права i характеризується тим, що, по-перше, має особливу підставу - екологічне правопорушення, а по-друге, передбачає застосування санкцій кримінально-правового, адміністративного, цивільно-правового, дисциплінарного характеру до осіб, що вчинили екологічне правопорушення [3, с. 127-128].

Отже, 3 урахуванням сучасних наукових позицій як теоретиків права, так і представників галузевих юридичних наук, зокрема у сфері екологічного права, вважаємо, що юридична відповідальність, у тому числі юридична відповідальність за порушення законодавства у сфері використання та охорони водних об'єктів, що віднесені до категорії лікувальних, полягає насамперед в обов'язку правопорушників понести несприятливі наслідки своєї неправомірної поведінки - застосування санкцій кримінально-правового, адміністративного, цивільно-правового, дисциплінарного характеру за вчинення правопорушення, передбаченого нормами природоресурсного та природоохоронного права тощо.

В. О. Джуган обгрунтовує, що особливості відповідальності за порушення водного 
законодавства полягають у специфіці водних об'єктів, у змісті шкоди, завданої водним об'єктам, та іншому [4, с. 125]. Зауважимо, що з урахуванням статті 62 Водного кодексу України [5], постанови Кабінету Міністрів України від 11 грудня 1996 р. № 1499 «Про затвердження переліку водних об’єктів, що відносяться до категорії лікувальних» [6] до водних об'єктів, що віднесені до категорії лікувальних, належать підземні (родовища мінеральних вод, родовища лікувальних грязей), а також поверхневі водні об'єкти (соляні озера (лимани)) загальнодержавного значення, які мають природне походження та включені до відповідного переліку.

Таким чином, залежно від специфіки та видів водних об'єктів, що віднесені до категорії лікувальних, можна запропонувати класифікацію юридичної відповідальності за порушення законодавства у цій сфері на: 1) юридичну відповідальність за порушення законодавства у сфері використання та охорони підземних водних об'єктів, що віднесені до категорії лікувальних, та 2) юридичну відповідальність за порушення законодавства у сфері використання та охорони поверхневих водних об'єктів, що віднесені до категорії лікувальних. Обгрунтованість такої класифікації зумовлюється рядом факторів, зокрема тим, що кожен із цих видів юридичної відповідальності урегульований відповідними галузевими нормами (водним законодавством, законодавством про надра тощо); відповідно, галузеве законодавство встановлюе досить широкий перелік порушень, за які настає юридична відповідальність.

Аналіз чинного законодавства України дає підстави для висновку, що перелік порушень вимог законодавства у сфері використання та охорони водних об'єктів, віднесених до категорії лікувальних, є невичерпним та має різногалузеву прописку.

Закон України «Про охорону навколишнього природного середовища» [7], зокрема стаття 68, передбачає, що порушення законодавства України про охорону навколишнього природного середовища тягне за собою встановлену законодавством України дисциплінарну, адміністративну, цивільну та кримінальну відповідальність.

Таким чином, найбільш поширеною в сучасний період є класифікація юридичної відповідальності на види за галузевою ознакою.

Водний кодекс України передбачає, що порушення водного законодавства тягне за собою дисциплінарну, адміністративну, цивільно-правову або кримінальну відповідальність згідно із законодавством України (ч. 1 ст. 110 Водного кодексу України) [5].
Це стосується насамперед поверхневих водних об'єктів (соляні озера (лимани)) загальнодержавного значення, які мають природне походження та які включені до відповідного переліку.

Частина 3 ст. 110 Водного кодексу України визначає види порушень, за вчинення яких винні особи несуть юридичну відповідальність, наприклад: самовільне захоплення водних об'єктів; забруднення та засмічення вод; недотримання умов дозволу або порушенні правил спеціального водокористування; самовільне проведення гідротехнічних робіт (будівництво ставків, дамб, каналів, свердловин); порушення правил ведення державного обліку вод або перекручення чи внесення недостовірних відомостей в документи державної статистичної звітності; пошкодження водогосподарських та гідрометричних споруд і пристроїв, порушення правил експлуатації та встановлених режимів їх роботи; використання земель водного фонду не за призначенням; неповідомлення (приховування) відомостей про аварійні ситуації на водних об'єктах; відмова від надання (приховування) проектної документації та висновків щодо якості проектів підприємств, споруд та інших об'єктів, що можуть впливати на стан вод, а також актів і висновків комісій, які приймали об'єкт в експлуатацію [5].

Оскільки підземні лікувальні води підпадають під регулювання також і законодавства про надра та включені до переліку корисних копалин, частиною 1 ст. 65 Кодексу України про надра передбачається можливість притягнення винних осіб до дисциплінарної, адміністративної, цивільно-правової і кримінальної відповідальності за порушення законодавства про надра. Загальний перелік правопорушень у сфері надрових відносин встановлений ч. 2 ст. 65 Кодексу України про надра. Так, відповідно до вказаної статті, відповідальність за порушення законодавства про надра несуть особи, винні, зокрема: у самовільному користуванні надрами; порушенні норм, правил і вимог щодо проведення робіт із геологічного вивчення надр; наднормативних втратах і погіршенні якості корисних копалин при їх видобуванні; пошкодженнях родовищ корисних копалин, які виключають повністю або суттєво обмежують можливість їх подальшої експлуатації; невиконанні правил охорони надр та вимог щодо безпеки людей, майна i навколишнього природного середовища від шкідливого впливу робіт, пов'язаних 3 користуванням надрами; знищенні або пошкодженні геологічних об'єктів, що становлять особливу наукову і культурну цінність, спостережних режимних свердловин, 
а також маркшейдерських і геодезичних знаків; незаконному знищенні маркшейдерської або геологічної документації, а також дублікатів проб корисних копалин, необхідних при подальшому геологічному вивченні надр і розробці родовищ; невиконанні вимог щодо приведення гірничих виробок і свердловин, які ліквідовано або законсервовано, в стан, який гарантує безпеку людей, а також вимог щодо збереження родовищ, гірничих виробок і свердловин на час консервації. Вказаний перелік не $\epsilon$ вичерпним, законодавчими актами України може бути встановлено відповідальність і за інші порушення законодавства про надра відповідно до ч. 3 ст. 65 цього кодексу [8].

Частина 1 ст. 104 Водного кодексу України закріплює положення про те, що охорона водних об'єктів, віднесених до категорії лікувальних, здійснюється в порядку, встановленому для санітарної охорони курортів [5]. Тому, враховуючи норми ст. 43 Закону України «Про курорти» [9], також можна стверджувати, що особи, винні в порушенні вимог законодавства про курорти, несуть цивільноправову, адміністративну або кримінальну відповідальність у встановленому законом порядку, за винятком дисциплінарної.

Водночас необхідно констатувати, що норми Водного кодексу України, Кодексу України про надра тощо мають бланкетний характер, тому регулятивного значення не мають, оскільки відповідальність за порушення водного, надрового законодавства, законодавства про курорти тощо, встановлена у статті, настає лише у тих випадках, коли вона передбачена відповідно Кодексом України про адміністративні правопорушення, Цивільним кодексом України, Кримінальним кодексом України.

Кримінальна відповідальність і адміністративна відповідальність, як загальноохоронні, настають за здійснення правопорушень практично у будь-якій галузі права; при цьому головним критерієм іх видової ідентифікації є ступінь суспільної небезпеки правопорушення.

Кримінальна відповідальність за злочини проти довкілля визначена Кримінальним кодексом України. Частина 2 ст. 240 Кримінального кодексу України передбачає кримінальну відповідальність за незаконне видобування корисних копалин загальнодержавного значення. Води, у тому числі і лікувальні, належать до корисних копалин загальнодержавного значення, тому виступають об'єктом даного злочину. Санкція цієї статті передбачає покарання у виді штрафу від чотирьохсот до семисот неоподатковуваних мінімумів доходів громадян, або обмеження волі на строк до трьох років, або позбавлення волі на той самий строк. Частина 1 ст. 242 Кримінального кодексу України закріплює кримінальну відповідальність за порушення правил охорони вод (водних об'єктів), якщо це спричинило забруднення поверхневих чи підземних вод і водоносних горизонтів, джерел питних, лікувальних вод, або зміну їхніх природних властивостей, або виснаження водних джерел і створило небезпеку для життя, здоров'я людей чи для довкілля. Водночас водні об'єкти, в тому числі і водні об'єкти, що віднесені до категорії лікувальних, виступають предметом даного злочину. Санкція цієї статті передбачає покарання у виді штрафу від ста до двохсот неоподатковуваних мінімумів доходів громадян, або позбавлення права обіймати певні посади чи займатися певною діяльністю на строк до п'яти років, або обмеження волі на той самий строк. Частина 2 ст. 242 КК України передбачає кваліфікуючі ознаки даного злочину, зокрема, якщо ті самі діяння, якщо вони спричинили загибель або захворювання людей, масову загибель об'єктів тваринного і рослинного світу або інші тяжкі наслідки. Санкція даної статті передбачає покарання у виді обмеження волі на строк до п'яти років або позбавлення волі на той самий строк [10].

Адміністративна відповідальність встановлена Кодексом України про адміністративні правопорушення [11], й у разі порушень законодавства про водні об'єкти, віднесені до категорії лікувальних, може кваліфікуватись за ст. ст. 57-59, 60 цього кодексу.

У наукових дослідженнях неодноразово наголошувалося на необхідності вдосконалення юридичної відповідальності, зокрема, щодо встановлення самостійних складів злочинів та адміністративних правопорушень у відносинах $з$ охорони та використання лікувально-оздоровчих територій та лікувальних ресурсів [12, с. 14; 13, с. 18; 14, с. 16]. Такі висновки заслуговують на підтримку та повинні знайти конкретизацію в подальших дослідженнях і належне закріплення в законодавстві.

Дисциплінарна відповідальність за екологічні правопорушення настає за вчинення дисциплінарного проступку під час виконання трудових обов'язків працівника, який порушує екологічне законодавство. Таким чином, суб'єктом дисциплінарної відповідальності може бути лише працівник, у чиї обов'язки входить дотримання таких норм. Кодекс законів про працю України [15] передбачає дисциплінарну відповідальність у вигляді догани і звільнення. Проте ці дисциплінарні стягнення можуть застосовуватись, якщо порушення вимог екологічного 
законодавства і правил внутрішнього розпорядку мали місце у робочий час.

Важливо також мати на увазі, що законодавець не встановлює переліку складів дисциплінарних екологічних проступків, тому об'єктом правопорушення є не лише екологічні відносини, а й правила внутрішнього розпорядку.

Крім того, дисциплінарна відповідальність може застосовуватися одночасно 3 іншими видами юридичної відповідальності, наприклад адміністративною чи цивільно-правовою. Водночас іiї застосування $є$ правом роботодавця.

Цивільно-правова відповідальність передбачає обов'язок понести несприятливі наслідки майнового характеру, що передбачені санкціями правових норм або у договорі. Ïї особливості полягають у тому, що правопорушення виражається у формі невиконання чи неналежного виконання зобов'язання або спричинення майнової чи моральної шкоди в результаті вчинення правопорушення, тобто є деліктним.

Водночас погоджуємось із Н. Р. Кобецькою в тому, що відносини з використання об'єктів природи не є тотожними майновим, цивільно-правовим відносинам. Їх специфіка зумовила особливості правового регулювання відносин з відшкодування шкоди, заподіяної природним об'єктам, що проявилось у встановленні особливого порядку відшкодування такої шкоди і стало підставою для обгрунтування в наукових джерелах існування самостійного виду відповідальності за екологічні правопорушення - матеріальної відповідальності. На думку автора, матеріальна відповідальність за шкоду природному середовищу є проявом цивільноправової відповідальності. У даному випадку матеріальна відповідальність за екологічні порушення $є$ цивільно-правовою відповідальністю і здійснюється вона відповідно до норм цивільного і цивільно-процесуального законодавства. Стаття 68 Закону України «Про охорону навколишнього природного середовища» передбачає обов'язок відшкодувати заподіяну шкоду, а ст. 69 Закону вказує на необхідність її компенсації в повному обсязі [3, с. 136].

Отже, несприятливі наслідки за правопорушення мають майновий характер і виконують компенсаційну функцію.

У контексті компенсаційної функції цивільно-правової відповідальності підлягають відшкодуванню збитки, завдані внаслідок порушень законодавства про водні об'єкти, віднесені до категорії лікувальних. Порядок розрахунку розмірів збитків, заподіяних об'єктам природи, є особливим та визначається на підставі затверджених законодавством такс чи методик. У розглядуваних нами відносинах можуть застосовуватись Методика розрахунку розмірів відшкодування збитків, заподіяних державі внаслідок порушення законодавства про охорону та раціональне використання водних ресурсів, затверджена наказом Міністерства охорони навколишнього природного середовища України від 20 липня 2009 р. № 389 [16] та Методика визначення розмірів відшкодування збитків, заподіяних державі внаслідок самовільного користування надрами, затверджена наказом Міністерства екології та природних ресурсів України від 29 серпня 2011 р. № 303 [17]. На підставі аналізу цих Методик можна виявити особливості розрахунку розмірів збитків, заподіяних лікувальним водним об'єктам. Насамперед, Методика визначення розмірів відшкодування збитків, заподіяних державі внаслідок самовільного користування надрами, не застосовується до підземних (в тому числі лікувальних) вод, які не включені в перелік мінеральних ресурсів, щодо яких визначені базові ставки збитків (Додаток 1 до Методики). У цьому додатку, однак, визначена базова ставка щодо лікувальних грязей, яка, щоправда, є одною 3 найнижчих і становить 0,96 м.з. пл./ т; куб. м; кг. Таким чином, ця Методика не враховуе лікувальну цінність відповідних ресурсів, a лише їх економічне значення порівняно 3 іншими корисними копалинами (нафтою, газом тощо).

Методика розрахунку розмірів відшкодування збитків, заподіяних державі внаслідок порушення законодавства про охорону та раціональне використання водних ресурсів, у формулі розрахунку розмірів збитків містить коефіцієнт, який залежить від категорії водного об’єкта. Ці коефіцієнти закріплені в Додатку 2 до Методики, серед яких коефіцієнт для підземних мінеральних вод $€$ найвищим $(5,0)$.

Як бачимо, законодавство містить лише окремі положення (у сфері цивільно-правової відповідальності), які для визначення відповідальності враховують особливості та цінність лікувальних вод.

На наш погляд, у законодавстві України, що регулює використання та охорону водних об'єктів, які віднесені до категорії лікувальних, доцільно закріпити принцип пріоритету натуральної форми відшкодування шкоди, заподіяної порушенням цього законодавства, тобто повного відновлення стану і втрачених функцій водного об'єкта, а також пов'язаних з ним інших елементів навколишнього природного середовища, постраждалих в результаті правопору- 
шення, відповідно до спеціально розроблених програм щодо використання, відновлення й охорони водних об'єктів, віднесених до категорії лікувальних.

На жаль, нині юридична відповідальність не є одним із найбільш ефективних правових засобів боротьби за збереження водних об'єктів, що віднесені до категорії лікувальних, і забезпечення їх раціонального використання та охорони, свідченням чого є нечисельна судова практика притягнення винних осіб до юридичної відповідальності за порушення законодавства у сфері використання та охорони водних об'єктів, що віднесені до категорії лікувальних.

Проте не всі дії, бездіяльність у сфері використання та охорони водних об'єктів, що віднесені до категорії лікувальних, є правопорушеннями, мають деліктний характер і вимагають застосування заходів юридичної відповідальності. У юридичній літературі, зокрема в екологічному праві, звертається увага на двоаспектність їі розуміння - позитивна та негативна [3, с. 128]. Негативна (ретроспективна) відповідальність - це відповідальність с суб'єкта-правопорушника перед державою, натомість позитивна (перспективна) відповідальність, у тому числі в галузі екології, виражається в усвідомленні особою своєї соціальної відповідальності перед іншими, перед суспільством, необхідності правомірної поведінки, тобто в ії̈ основі лежать певні соціально-моральні цінності, усвідомлення обов'язку дбайливого ставлення до навколишнього природного середовища. Водночас як негативна, так і позитивна відповідальність базується на відповідних правових нормах. Позитивна (перспективна) відповідальність виникає з юридичного обов'язку здійснювати позитивні, корисні для суспільства функції і ролі. Вона реалізується в регулятивних, а не охоронних правовідносинах, як негативна (ретроспективна).

На думку В. I. Івакіна, застосування позитивної відповідальності пов'язане з тим, що особі надаються певні додаткові права і можливості. Це знаходить своє вираження в позитивних наслідках різного характеру: майновому, організаційному й особистому і є формою реалізації екологічної санкції, проте не ототожнюється з нею. Як правило, застосовується в особливій процесуальній формі. Підставою служать тільки певні заслуги. Структура позитивної екологічної відповідальності також відмінна від негативної: в першій відсутнє саме екологічне правопорушення. За умислом ці поняття також різні. Якщо у разі ретроспективної відповідальності умисел може бути як прямий, так і непрямий, то позитивна відповідальність означає, що особа добре усвідомлює наслідки своїх дій і їх виконує. Санкції також різняться. Об'єктивна сторона у разі позитивної відповідальності, як правило, виражається в діях, але не виключається і бездіяльність. Ретроспективна відповідальність передбачає як дії, так і бездіяльність [18, с. 154].

Н. А. Берлач відзначає, що позитивна юридична відповідальність має превентивний характер і її необхідно розглядати як відповідну реакцію держави на вчинене особою правомірне діяння з метою заохочення суспільно-корисної поведінки суб'єктів правовідносин [19, с. 78].

У контексті необхідності посилення правової охорони водних об'єктів, що віднесені до лікувальних, роль позитивної відповідальності повинна зростати. Погоджуємось із М. В. Красновою в тому, що цьому виду еколого-правової відповідальності має відповідати належний рівень морально-етичного ставлення кожного до природи як до місця й умови існування всього живого на Землі, принаймні такий, який існував у поведінці пращурів та зберігся в окремих звичаях і традиціях нашого народу [20, с. 217].

\section{Висновки}

Виходячи з проведеного аналізу нормативних положень законодавства України у сфері використання та охорони водних об'єктів, що віднесені до категорії лікувальних, можна зробити ряд висновків щодо юридичної відповідальності:

- водні об'єкти, віднесені до категорії лікувальних, є об'єктом регулювання водного законодавства та законодавства про надра, зокрема що стосується користування підземними лікувальними водами та тими, що включені до переліку корисних копалин;

- перелік порушень вимог законодавства у сфері використання та охорони водних об'єктів, віднесених до категорії лікувальних, $€$ невичерпним та має різногалузеву прописку;

- за порушення користування лікувальними водними об'єктами передбачена юридична відповідальність, зокрема: адміністративна, кримінальна, дисциплінарна, цивільно-правова відповідальність.

На основі проведеного дослідження можна зробити узагальнення що, інститут юридичної відповідальності за порушення законодавства про водні об'єкти, віднесені до категорії лікувальних, потребує удосконалення. Насамперед це стосується посилення адміністративної, кримінальної та цивільноправової відповідальності за порушення режиму використання та охорони водних 
об’єктів, віднесених до категорії лікувальних; необхідності формування самостійних складів злочинів та адміністративних правопорушень, які були б достатньою підставою для притягнення до відповідальності за порушення законодавства у сфері використання та охорони водних об'єктів, що віднесені до категорії лікувальних.

У контексті необхідності посилення правової охорони водних об'єктів, що віднесені до категорії лікувальних, роль позитивної відповідальності повинна зростати, оскільки спрямована на заохочення правомірної та відповідальної поведінки під час використання цих об'єктів. А це зрештою зменшує ризики негативного антропогенного впливу на водні об'єкти, що віднесені до категорії лікувальних, та навколишнє природне середовище загалом. Отже, і законодавство України у цій сфері повинно бути удосконалене.

\section{Список використаних джерел:}

1. Вирок Вінницького районного суду Вінницької області, судова справа № 1-433/11. URL: http://www.reyestr.court.gov. ua/Review/21948471 (дата звернення: 05.01.2019).

2. Екологічне право України : підручник для студентів юрид. вищ. закладів / за ред. А. П. Гетьмана, М. В. Шульги. Харків: Право, 2005. 382 с.

3. Кобецька Н.Р. Екологічне право України : навчальний посібник. Київ : Юрінком Інтер, 2008. $352 \mathrm{c}$.

4. Джуган, В.О. Правове регулювання використання та охорони вод в Україні : дис. ... канд. юрид. наук: 12.00.06. Київ, 2009. 195 с.

5. Водний кодекс України : Закон України від 06.06.1995 № 213/95-BP. URL: https://zakon.rada. gov.ua/laws/show/213/95-\%D0\%B2\%D1\%80 (дата звернення: 05.01.2019).

6. Про затвердження переліку водних об'єктів, що відносяться до категорії лікувальних : Постанова Кабінету Міністрів України від 11.12.1996 № 1499. URL: https://zakon.rada.gov. ua/laws/main/1499-96-\%D0\%BF (дата звернення: 05.01.2019).

7. Про охорону навколишнього природного середовища : Закон України від 25.06.1991 № 1264-XII. URL: https://zakon.rada. gov.ua/laws/show/1264-12 (дата звернення: 05.01.2019).

8. Кодекс України про надра : Закон України від 27.07.1994 № 132/94-BP. URL: http://zakon3. rada.gov.ua/laws/show/132/94-вр. (дата звернення: 05.01.2019).
9. Про курорти : Закон України від 05.10.2000 № 2026-III. Офімійний вісник України. 2000. № 44. Ст. 35.

10. Кримінальний кодекс України : Закон України від 05.04.2001 № 2341-III. Відомості Верховної Ради Украӥни. 2001. № 25-26. Ст. 131.

11. Кодекс України про адміністративні правопорушення: Закон Української РСР від 07.12.1984 № 8073-X. URL: http://zakon2.rada. gov.ua/laws/show/80731-10. (дата звернення: 05.01.2019).

12. Петлюк Ю.С. Правовий режим земель оздоровчого призначення : автореф. дис. ... канд. юрид. наук: 12.00.06. Київ, 2009. 16 с.

13. Орлов А. М. Правові проблеми природокористування й охорони навколишнього середовища оздоровчих та рекреаційних місцевостей (на матеріалах Автономної Республіки Крим) : автореф. дис. ... канд. юрид. наук: 12.00.06. Київ, 2005. 21 с.

14. Булах І. Г. Правове регулювання використання та охорони земель оздоровчого призначення : автореф. дис. ... канд. юрид. наук: 12.00 .06 . Донецьк, 2010. 19 с.

15. Кодекс законів про працю України від 10.12.1971 № 322-VIII. URL: zakon5.rada.gov.ua/ laws/show/322-8 (дата звернення: 05.01.2019).

16. Про затвердження Методики розрахунку розмірів відшкодуваннязбитків,заподіянихдержаві внаслідок порушення законодавства про охорону та раціональне використання водних ресурсів : наказ Міністерства охорони навколишнього природного середовища від 20.07.2009 № 389. URL: https:// zakon.rada.gov.ua/laws/show/z0767-09 (дата звернення: 05.01.2019).

17. Про затвердження Методики визначення розмірів відшкодування збитків, заподіяних державі внаслідок самовільного користування надрами : наказ Міністерства екології та природних ресурсів України від 29.08.2011 № 303. URL: https://zakon.rada.gov.ua/laws/show/ z1097-11(дата звернення: 05.01.2019).

18. Ивакин В. И. Теоретические проблемы формирования и развития эколого-правовой ответственности : монография. Москва : Изд-во Юридического института МИИТ, 2017. 290 с.

19. Берлач Н. А. Перспективи розвитку позитивної юридичної відповідальності в демократичному суспільстві. Форум права. 2012. № 1. С. 77-81. URL: http://nbuv.gov.ua/UJRN/FP_index (дата звернення: 05.01.2019).

20. Краснова М. В. Проблеми визначення поняття екологічної відповідальності за законодавством України. Університетські наукові записки. 2011. № 1. C. 216-222. URL:http://nbuv. gov.ua/UJRN/Unzap_2011_1_36 (дата звернення: 05.01.2019)

Based on the research, the article indicates that the problem of legal liability for violations of legislation in the field of use and protection of water objects, which are categorized as therapeutic, is not complexly solved in the Ukrainian legislation. Some scientific discussions are still taking place in order to understand the nature of legal responsibility, its types etc.

Taking into account the current scientific positions of both: legal theorists and representatives of the field of legal science, in particular in the field of environmental law, it is proposed to consider legal liability, 
including legal responsibility for violations of legislation in the field of use and protection of water objects that are categorized as therapeutic, as a duty of the offenders to get the adverse consequences of their misconduct, resulting in the application of sanctions under criminal law, administrative law, civil law and disciplinary liability for committing the offences stipulated by the norms of natural resources and nature conservation law etc.).

Water objects that are categorized as therapeutic have significant features, that is why there is a need to differentiate legal regulations of relationships related to the legal liability of this sphere. Therefore, the problem has become methodologically important, and in near future it will become worldview issue, which in turn leads to a new aspect about the relevance of legal responsibility for violations of legislation in this area.

Depending on the specificity and types of water objects that are categorized as therapeutic, the classification of types of legal liability forviolation of legislation in this field includes two groups of offences: 1) legal liability for violation of legislation in the field of use and protection of underground water objects, which are referred to the category of therapeutic; and 2) legal liability for violations of legislation in the field of use and protection of surface water objects that are categorized as therapeutic.

However, nowadays the most common is the classification of legal liability for types by branches.

Legal liability for violations of the legislation in the field of use and protection of water objects, which are categorized as therapeutic, is justified as a two-aspect phenomenon, manifested in negative (retrospective) and positive (prospective) liability.

Key words: legal liability, positive legal responsibility, negative legal liability, water objects, that are categorized as therapeutic. 